\title{
Recognition for Capstone Design Based on the Majors of College Students
}

\author{
Sun-Ju Kim \\ Department of Dental Hygiene, School of Health Sciences, \\ Cheongju University, Cheongju, 28503, Korea \\ sjkim@cju.ac.kr
}

\begin{abstract}
This study assesses the recognition and needs of university students regarding capstone design classes based on their majors. The overall score regarding recognition of capstone design was 3.26 points, which implied that students understood the significance of capstone design classes but had a weak understanding of capstone design. Students in science and engineering also showed higher recognition than those in other fields. The need for capstone design classes was strongest among students in the science and engineering fields but was relatively weak among students in the humanities and social sciences fields. This study is significant in that it can be used as basic data for designing the direction of capstone design courses and developing teacher-student programs that fit the consumer.
\end{abstract}

Keywords: College student, recognition, need, major, capstone design

\section{Introduction}

The definition of capstone design differs between scholars, but it is generally defined as an education program with a comprehensive design for planning, designing, and producing so that students can develop their ability to solve issues they may encounter in the actual world alongside other students, teachers, and a field expert, to train creative and talented individuals to adapt to their field and meet the needs of businesses [1][2][3]. While the engineering field has been relatively active in conducting creative design education programs, such as capstone design classes, the humanities and social sciences, health, and art fields have not provided their students with many opportunities to experience various creative convergence class activities that could strengthen their ability to handle problems they may encounter in society after graduation or practical field competence.

Several recent studies proved that capstone design classes improve the creative problemsolving skills of students and increase academic achievement and satisfaction [4][5][6][7]. However, regardless of how brilliant an education program maybe, if the students are unable to properly understand the intention and content of the course, it will not only fail to increase student participation in class but will also face difficulty in instituting efficient learning [8].

Therefore, this study will assess the recognition of and need for capstone design classes among university students according to their majors, so that it can be used as basic data for designing the direction of capstone design courses.

\section{Research method}

Article history:

Received (February 2, 2018), Review Result (February 26, 2018), Accepted (March 29, 2018) 


\subsection{Research subjects}

This study presents a descriptive survey on the recognition and needs of university students regarding capstone design classes according to their major field. A structured, self-report survey was conducted from November 30, 2017 to December 14, 2017. A total of 341 surveys were used in the final analysis.

\subsection{Research method}

\subsubsection{Recognition of capstone design classes}

The part of the survey on the subject's recognition of capstone design classes included five questions. Each question was measured on a five-point Likert scale, and higher scores implied that the subject had a higher recognition of capstone design classes.

\subsubsection{The need for capstone design classes}

The part of the survey on the need for capstone design classes included 10 questions. Higher scores implied that the subject showed a stronger need for capstone design classes.

\subsection{Analysis method}

The collected data were analyzed using SPSS WIN/PC 19.0. The average and standard deviation were calculated for the recognition of and need for capstone design classes. The difference between each variable according to subject characteristics was analyzed using a ttest and ANOVA, while the Scheffe test was performed for the post-test. Statistical significance levels were set to $\mathrm{p}<0.05$.

\section{Research results}

\subsection{General characteristics of the research subjects}

A total of $45.5 \%$ of the subjects in this study were male students and $54.5 \%$ were female. In terms of year, $47.8 \%$ were third-year students and $52.5 \%$ were in their fourth year. Concerning the subjects' majors, $30.2 \%$ were in the health field, $29.0 \%$ in the science and engineering field, $23.5 \%$ in the humanities and social science field, and $17.3 \%$ in the art field [Table 1].

Table 1. General characteristics of the research subjects

\begin{tabular}{|c|c|c|c|}
\hline \multicolumn{2}{|c|}{ Category } & N & \% \\
\hline \multirow{3}{*}{ Gender } & Male & 155 & 45.5 \\
\cline { 2 - 4 } & Female & 186 & 54.5 \\
\hline \multirow{2}{*}{ Year } & Third Year & 163 & 47.8 \\
\cline { 2 - 4 } & Fourth Year & 178 & 52.2 \\
\hline \multirow{2}{*}{ Field } & Science and Engineering & 99 & 29.0 \\
\cline { 2 - 4 } & Health & 103 & 30.2 \\
\hline
\end{tabular}




\begin{tabular}{|c|c|c|c|}
\hline & $\begin{array}{c}\text { Humanities and Social } \\
\text { Science }\end{array}$ & 80 & 23.5 \\
\cline { 2 - 4 } & Art & 59 & 17.3 \\
\hline
\end{tabular}

\subsection{Experience with capstone design classes according to general characteristics}

When it came to experience with capstone design classes according to general characteristics, there were significant differences in gender, year and major. Male students had more experience with capstone design classes than females, and fourth-year students had more experience than third-year ones. Based on majors, the proportion of non-engineering majors with experience with capstone design classes was extremely low [Table 2].

Table 2. Experience with capstone design classes according to the general characteristics of the research subjects

\begin{tabular}{|c|c|c|c|c|c|c|}
\hline \multirow{2}{*}{\multicolumn{2}{|c|}{ Variables }} & \multicolumn{3}{|c|}{ Experience with Capstone Design Class } & \multirow{2}{*}{$\chi^{2}$} & \multirow{2}{*}{ p-value } \\
\hline & & Yes & No & Total & & \\
\hline \multirow{2}{*}{ Gender } & Male Students & $53(34.2)$ & $102(65.8)$ & $155(100.0)$ & \multirow{2}{*}{3.249} & \multirow{2}{*}{$0.046 *$} \\
\hline & Female Students & $47(25.3)$ & $139(74.7)$ & $186(100.0)$ & & \\
\hline \multirow{2}{*}{ Year } & Third Year & $24(14.7)$ & $139(85.3)$ & $186(100.0)$ & \multirow{2}{*}{32.123} & \multirow{2}{*}{$<0.001 * * *$} \\
\hline & Fourth Year & $76(42.7)$ & $102(57.3)$ & $187(100.0)$ & & \\
\hline \multirow{4}{*}{ Field } & $\begin{array}{l}\text { Science and } \\
\text { Engineering }\end{array}$ & $76(76.8)$ & $23(23.2)$ & $99(100.0)$ & \multirow{4}{*}{42.670} & \multirow{4}{*}{$<0.001 * * *$} \\
\hline & Health & $12(11.7)$ & $91(88.3)$ & $103(100.0)$ & & \\
\hline & $\begin{array}{l}\text { Humanities and } \\
\text { Social Science }\end{array}$ & $2(2.5)$ & $78(97.5)$ & $80(100.0)$ & & \\
\hline & Art & $10(16.9)$ & $49(83.1)$ & $59(100.0)$ & & \\
\hline
\end{tabular}

$*_{p}<.05, * * p<.01, * * * p<.001$, statistically significant by $\chi^{2}$

\subsection{Degree of recognition of capstone design classes according to the general characteristics of the research subjects}

The degree of recognition of capstone design classes was higher among male students than female students, and among fourth-year students than third-year students. Students in science and engineering also showed higher recognition than those from other fields [Table 3].

Table 3. Recognition of capstone design classes according to the general characteristics of the research subjects

\begin{tabular}{|l|c|c|c|}
\hline \multicolumn{2}{|c|}{ Variables } & $\mathrm{M} \pm \mathrm{SD} \dagger$ & $\mathrm{p}$-value \\
\hline \multirow{2}{*}{ Gender } & Male Students & $3.38 \pm 0.89$ & 0.076 \\
\hline
\end{tabular}




\begin{tabular}{|c|c|c|c|}
\hline & Female Students & $3.11 \pm 0.94$ & \\
\hline \multirow{4}{*}{ Year } & Third Year & $2.82 \pm 0.66$ & $<0.001^{* * * *}$ \\
\cline { 2 - 3 } & Fourth Year & $3.69 \pm 0.89$ & \\
\hline \multirow{4}{*}{ Field } & Science and Engineering & $3.68 \pm 0.70^{\mathrm{a}}$ & \multirow{2}{*}{$<0.001^{* * *}$} \\
\cline { 2 - 3 } & Health & $3.47 \pm 0.86^{\mathrm{a}}$ & \\
\cline { 2 - 4 } & $\begin{array}{c}\text { Humanities and Social } \\
\text { Science }\end{array}$ & $2.20 \pm 0.75^{\mathrm{c}}$ & \\
\cline { 2 - 4 } & Art & $3.19 \pm 0.95^{\mathrm{b}}$ & \\
\hline
\end{tabular}

$\dagger M \pm S D:$ mean \pm standard deviation

${ }^{*} p<.05, * * p<.01, * * * p<.001$, statistically significant by one-way ANOVA

a.b.c. : different letters represent significant difference by Scheffe method comparison at 0.05 significance level

\subsection{Degree of need for capstone design classes according to the general characteristics of the research subjects}

The degree of need for capstone design classes was higher among male students than female students, and among fourth-year students than third-year students. Based on major, the degree of need was highest among students in the science and engineering field but was relatively low among students in the humanities and social sciences field [Table 4].

Table 4. The need for capstone design classes according to the general characteristics of the research subjects

\begin{tabular}{|c|c|c|c|}
\hline \multicolumn{2}{|c|}{ Variables } & $\mathrm{M} \pm \mathrm{SD} \uparrow$ & p-value \\
\hline \multirow{2}{*}{ Gender } & Male Students & $3.65 \pm 0.92$ & \multirow{2}{*}{$<0.001 * * *$} \\
\hline & Female Students & $3.41 \pm 1.02$ & \\
\hline \multirow{2}{*}{ Year } & Third Year & $3.03 \pm 0.90$ & \multirow{2}{*}{$<0.001 * * *$} \\
\hline & Fourth Year & $3.96 \pm 0.83$ & \\
\hline \multirow{4}{*}{ Field } & Science and Engineering & $4.08 \pm 0.72^{\mathrm{a}}$ & \multirow{4}{*}{$<0.001 * * *$} \\
\hline & Health & $3.93 \pm 0.88^{\mathrm{ab}}$ & \\
\hline & $\begin{array}{c}\text { Humanities and Social } \\
\text { Science }\end{array}$ & $2.80 \pm 01.01^{\mathrm{c}}$ & \\
\hline & Art & $3.62 \pm 0.90^{\mathrm{b}}$ & \\
\hline
\end{tabular}

$广 M \pm S D:$ mean \pm standard deviation

${ }^{*} p<.05, * * p<.01, * * * p<.001$, statistically significant by one-way ANOVA

a.b.c. : different letters represent significant difference by Scheffe method comparison at 0.05 significance level 


\section{Discussion and conclusion}

The overall score regarding recognition of capstone design was 3.26 points, which implied that students understood the significance of capstone design classes but had a weak understanding of capstone design. Students in science and engineering also showed higher recognition than those in other fields. The need for capstone design classes was strongest among students in the science and engineering fields but was relatively weak among students in the humanities and social sciences fields. The results of this study cannot be generalized since it focused on students from only some universities, but the study still holds significance in that it assessed the recognition of and need for capstone design classes targeting students from various majors.

\section{References}

[1] I. S. Park, and D. K. Kim, "A study on dental hygiene student effects of team-based learning in the dental hygiene curriculum on learning motivation and self-directed learning capabilities," J Korean Soc Dent Hyg, vol.10, no.1, pp.127-140, (2010)

[2] Y. H. Noh, "A study on the LIS capstone design curriculum and the learning satisfaction survey," Journal of Korean Library and Information Science Society, vol.46, no.3, pp.89-118, (2015),

[3] J. H. Jung, "A study on the effect and the development of creative engineering technology education program based on capstone design in elementary," Journal of Korean Practical Arts Education, vol.25, no.4, pp.195-215, (2012)

[4] E. H. Kim, Y. G. Ko, and S. N. Kim, "Effects of a capstone nursing research course for nursing students," The Journal of Learner-Centered Curriculum and Instruction, vol.16, no.10, pp.473-492, (2016)

[5] G. Y. Choi, and H. S. Kwon, "An analysis of the decision-making process in the dept. of dental hygiene curriculum,” Journal of Employment and Skills Development, vol.13, no.3, pp.199-220, (2010)

[6] S. J. Kim, and H. H. Kim, "Impact of communication competence and empathy abilities on interpersonal relationship abilities among dental hygiene students," J Dent Hyg Sci, vol.13, no.3, pp.304-313, (2013)

[7] M. H. Yoon, "Capston design applications and performance in the field of design," Journal of Korea Contents Association, vol.12, no.12, pp.111-118, (2012)

[8] J. M. Tae, I. J. Koh, J. H. Park, and C. Y. Kim, "Recognition and Needs about a Capstone Design Course for University Students Who Major in Nonengineering," Journal of Curriculum Integration, vol.11, no.3, pp.109130, (2017) 
Recognition for Capstone Design Based on the Majors of College Students

This page is empty by intention. 